\title{
PENGARUH PENGEMBANGAN KARIR, SEMANGAT KERJA \\ DAN MOTIVASI TERHADAP KINERJA KARYAWAN PT.PERKEBUNAN NUSANTARA II MEDAN
}

\author{
SARIMONANG SIHOMBING ${ }^{1}$ \\ ANDIKA NURMALASARI GULTOM ${ }^{2}$ \\ ${ }^{1}$ Program Studi Manajemen Fakultas Ekonomi Universitas Katolik Santo Thomas \\ ${ }^{1}$ E-mail : sarimonangsihombing@gmail.com \\ ${ }^{2}$ E-mail : gultomandikanurmalasari@gmail.com
}

\begin{abstract}
Abstrak
Penelitian ini bertujuan untuk menguji dan menganalisis pengaruh pengembangan karir, semangat kerja dan motivasi terhadap kinerja karyawan pada PT.Perkebunan Nusantara II Medan. Populasi dalam penelitian ini berjumlah 140 orang, yaitu karyawan bagian SDM di PT.Perkebunan Nusantara II Medan. Sampel berjumlah 58 orang, yang diperoleh dengan menggunakan metode proporsaional random sampling. Metode analisis yang digunakan dalam penelitian ini adalah analisis regresi berganda.Berdasarkan pengujian hipotesis secara parsial (Uji t) diketahui bahwa pengembangan ksrir berpengsruh positif dan signifikan terhadap kinerja karyawan pada PT.Perkebunan Nusantara II Medan. Hal ini dapat dilihat dari nilai sig. pengembangan karir $(0,045)<\alpha(0,05)$ atau nilai $t_{\text {hit }}(2,056)>t$ tab $(1,673)$. Semangat kerja berpengaruh positif dan signifikan terhadap kinerja karyawan pada PT.Perkebunan Nusantara II Medan. Hal ini dapat dilihat dari nilai sig. semangat kerja $(0,000)<\alpha(0,05)$ atau nilai $t_{\text {hit }}(3,929)>t_{\text {tab }}(1,673)$. Motivasi berpengaruh positif dan signifikan terhadap kinerja karyawan. Hal ini dapat dilihat dari nilai sig. motivasi $(0,004)<\alpha(0,05)$ atau nilai $t_{\text {hit }}(3,009)>t$ tab $(1,673)$. Semangat kerja berpengaruh positif dan signifikan terhadap kinerja karyawan pada PT.Perkebunan Nusantara II Medan.Pengujian hipotesa secara simultan (Uji F) menunjukkan bahwa pengembangan karir, semangat kerja dan motivasi, secara bersama-sama berpengaruh signifikan terhadap kinerja karyawan. Hal ini dilihat dari nilai sig. $(0,000)<\alpha(0,05)$ atau nilai $F_{\text {hit }}\left(29,142>\right.$ nilai $\left.F_{\text {tab }} 2,78\right)$. Dari hasil pembahasan diperoleh persamaan regresi linier berganda sebagai berikut: $\mathrm{Y}=4,234+$ $0,226 \mathrm{X}_{1}+0,366 \mathrm{X}_{2}+0,233+$ e. Dari persamaan regresi di atas dapat dilihat bahwa ketiga variabel bebas (pengembangan karir, semangat kerja dan motivasi) mempunyai hubungan positif dengan kinerja karyawan pada PT.Perkebunan Nusantara II Medan. Koefisien determinasi $\left(\mathrm{R}^{2}\right)$ sebesar 0,618 , artinya bahwa variasi kinerja karyawan mampu dijelaskan pengembangan karir, semangat kerja dan motivasi sebesar $61,8 \%$, sedangkan sisanya yaitu sebesar $38,2 \%$ dijelaskan oleh variabel lain yang tidak masuk dalam model.
\end{abstract}

Kata Kunci: pengembangan karir, semangat kerja, motivasi, kinerja karyawan.

\section{PENDAHULUAN}

Pada dasarnya setiap perusahaan, baik yang berskala besar maupun kecil, mempunyai harapan bahwa kelak dikemudian hari akan mengalami perkembangan yang pesat. Untuk mencapai perkembangan yang pesat, 
maka perusahaan harus mempunyai kinerja yang baik melalui sumber daya manusia yang dimiliki. Kinerja sumber daya manusia dipengaruhi oleh banyak faktor, antara lain:pengembangan karir, semangat kerja dan motivasi.

Menurut Sunyoto $(2012 ; 183)$, pengembangan karir adalah proses mengidentifikasi potensi karir pegawai dan materi serta menerapkan caracara yang tepat untuk mengembangkan potensi tersebut. Menurut Martoyo (2007;74), pengembangan karir adalah suatu kondisi yang menunjukkan adanya peningkatan-peningkatan status seseorang dalam suatu organisasi dalam jalur karir yang telah ditetapkan dalam organisasi yang bersangkutan.

Pernyataan ini juga didukung penelitian yang dilakukan oleh Pitami (2013) dengan judul "Pengaruh Pengembangan Karir Terhadap Kinerja Karyawan pada Perusahaan Daerah Air Minum (PDAM) Kudus. Hasil penelitian menunjukkan bahwa pengembangan karir berpengaruh positif dan signifikan terhadap kinerja karyawan.

Motivasi menurut Syadam (2005) merupakan semua kekuatan yang ada dalam diri seseorang yang memberi daya, memberi arah dan memelihara tingkah laku. Menurut Mathis dan Jakson (2001), motivasi merupakan hasrat dalam diri seseorang yang menyebabkan orang tersebut melakukan tindakan. Sedangkan Flippo (2000) menyatakan bahwa motivasi adalah ketrampilan dalam memadukan kepentingan karyawan dan kepentingan organisasi, sehingga keinginan karyawan dapat dipuaskan bersamaan dengan tujuan organisasi.

Kinerja karyawan menurut Mangkunegara (2000;67) merupakan prestasi kerja atau hasil kerja, baik kuantitas maupun kualitas yang dicapai oleh seorang karyawan per satuan periode waktu dalam melaksanakan tugas kerjanya sesuai dengan tanggung jawab yang diberikan kepadanya. Setiap organisasi atau instansi dalam melaksanakan program yang diarahkan selalu berdaya guna untuk mencapai tujuan perusahaan. Kinerja dapat diukur dari hasil kerja, pengetahuan pekerjaan, inisiatif, kecekatan mental, sikap, komunikasi yang baik.

PT.Perkebunan Nusantara II Medan merupakan salah satu badan usaha milik negara (BUMN) yang bergerak di bidang perkebunan. Perusahaan ini mengelola budi daya kelapa sawit, karet, tembakau dan tebu. Tanaman ini memerlukan kecermatan mulai dari penanaman sampai berproduksi sehingga karyawan dituntut bekerja secara optimal untuk mendapatkan hasil yang baik. Agar kualitas kerja dapat tercapai maka setiap tenaga kerja harus memiliki semangat kerja dan motivasi. 
Kinerja karyawan PT.Perkebunan Nusantara II Medan diukur berdasarkan kemampuan karyawan mencapai standar penilaian yang ditetapkan perusahaan seperti ditunjukkan dalam tabel berikut:

Tabel. 1.

Kinerja karyawan PT.Perkebunan Nusantara II Medan tahun 2013 - 2017 bagian SDM

\begin{tabular}{|c|c|c|c|c|}
\hline \multirow{2}{*}{ Tahun } & \multirow{2}{*}{$\begin{array}{c}\text { Jumlah } \\
\text { Karyawan } \\
\text { (orang) }\end{array}$} & $\begin{array}{c}|c| \\
\text { penilaian } \\
\text { karyawan }\end{array}$ & $\begin{array}{c}\text { Kealisasi } \\
\text { penilaian } \\
\text { karyawan }\end{array}$ & $\begin{array}{c}\text { \% Realisasi } \\
\text { penilaian } \\
\text { karyawan }\end{array}$ \\
\hline 2013 & 140 & 130 & 125 & 89,28 \\
\hline 2014 & 140 & 125 & 115 & 82,14 \\
\hline 2015 & 140 & 130 & 120 & 85,71 \\
\hline 2016 & 140 & 120 & 105 & 75,00 \\
\hline 2017 & 140 & 125 & 120 & 85,71 \\
\hline
\end{tabular}

Sumber: PT.Perkebunan Nusantara II Medan

Berdasarkan tabel 1 di atas, dapat dilihat bahwa standar penilaian karyawan dari tahun 2013 - 2017 tidak tercapai dan realisasinya berfluktuasi, capaian terendah terjadi pada tahun 2016 yaitu hanya $75 \%$. Ketidak tercapaian tersebut akan dianalisis dari segi pengembangan karir karyawan, semangat kerja karyawan dan motivasi. Penilaian kinerja pada perusahaan ini diukur melalui beberapa hal yaitu: kecekatan karyawan, apakah mampu menyelesaikan tugas-tugas dengan efektif dan efisien sebelum tanggal 5 setiap bulan yang merupakan tanggal terahir dalam menyelesaikan tugas. Berdasarkan uraian di atas, maka penulis tertarik unruk melakukan penelitian dengan judul: "Pengaruh Pengembangan Karir, Semangat Kerja dan Motivasi Terhadap Kinerja Karyawan Pada PT.Perkebunan Nusantara II Medan.

\section{TINJAUAN PUSTAKA}

\section{Indikator Pengembangan Karir}

Menurut Sunyoto $(2012 ; 173)$, ada lima indikator yang terkait dengan pengembangan karir karyawan:

a. Keadilan dalam karir, karyawan menghendaki keadilan dalam sistem promosi dengan kesempatan sama untuk peningkatan karir. 
b. Perhatian penyelia, para karyawan menginginkan penyelia mereka memainkan peran aktif dalam pengembangan karir, dan menyediakan umpan balik dengan teratur tentang prestasi.

c. Kesadaran tentang kesempatan, karyawan menghendaki pengetahuan tentang kesempatan untuk peningkatan karir.

d. Minat pekerja, para karyawan membutuhkan sejumlah informasi berbeda dan pada kenyataannya memiliki derajat yang berbeda dalam peningkatan karir yang tergantung pada beragam faktor.

e. Kepuasan karir, para karyawan tergantung pada usia dan kedudukan mereka dan memiliki tingkat kepuasan yang berbeda.

Selain itu, Siagian (2011) menyatakan, berbagai indikator yang perlu dipertimbangkan dalam pengembangan karir adalah sebagai berikut:

a. Perlakuan yang adil dalam berkarir. Perlakuan yang adil itu hanya bisa terwujud apabila kriteria promosi didasarkan pada pertimbanganpertimbangan yang objektif, rasional dan diketahui secara luas di kalangan pegawai.

b. Kepedulian para atasan langsung. Para pegawai pada umumnya mendambakan keterlibatan atasan langsung mereka dalam perencanaan karir masing-masing

c. Informasi tentang berbagai peluang promosi. Para pegawai pada umumnya mengharapkan bahwa mereka memiliki akses kepada informasi tentang berbagai peluang untuk dipromosikan.

d. Adanya minat untuk dipromosikan. Pendekatan yang tepat digunakan dalam hal menumbuhkan minat para pegawai untuk pengembangan karir ialah pendekatan yang fleksibel dan proaktif.

e. Tingkat kepuasan. Meskipun secara umum dapat dikatakan bahwa setiap orang ingin meraih kemajuan, termasuk dalam meniti karir, ukuran keberhasilan yang digunakan memang berbeda-beda.

\section{Semangat Kerja}

Menurut Nitisemito (2006:57) indikator untuk mengukur semangat kerja adalah:

a. Absensi, karena absensi menunjukkan ketidak hadiran karyawan dalam tugasnya. Hal ini termasuk waktu yang hilang karena sakit, kecelakaan dan pergi meninggalkan pekerjaan karena alasan pribadi.

b. Kerjasama dalam bentuk tindakan kolektif seseorang terhadap orang lain. 
c. Kepuasan, adalah sikap para karyawan yang menunjang tingkat kepuasan terhadap tugasnya, lingkungan perusahaan, serta jaminanjaminan yang diperolehnya meliputi tingkat kepuasan terhadap tugas dan pekerjaannya.

d. Sikap dan tingkah laku yang sesuai peraturan organisasi dalam bentuk tertulis maupun tidak

e. Disiplin, adalah ketaatan setiap karyawan terhadap tata tertib yang berlaku dalam perusahaan tersebut, meliputi kepatuhan karyawan pada jam kerja, kepatuhan karyawan pada perintah pimpinan serta taat pada tata tertib yang berlaku.

Menurut Taufiq (2000:14) indikator-indikator yang digunakan untuk mengukur semangat kerja sebagai berikut:

a. Absensi, menunjukkan ketidak hadiran para karyawan dalam tugasnya. Hal ini termasuk waktu yang hilang karena sakit, kecelakaan dan kepentingan-kepentingan pribadi.

b. Kerjasama, merupakan suatu tindakan bersama-sama antara seseorang dengan yang lain dimana setiap orang bekerja dan menyumbangkan tugasnya secara sukarela dan sadar untuk saling membantu guna mencapai tujuan bersama.

c. Disiplin, adalah ketaatan setiap karyawan terhadap tata tertib yang berlaku dalam perusahaan tersebut, meliputi: kepatuhan para karyawan pada jam-jam kerja, kepatuhan karyawan kepada perintah pimpinan serta taat kepada tata tertib yang berlaku, berpakaian seragam ke tempat kerja, bekerja sesuai dengan tanggung jawab, dan hasil kerja diharapkan menurut rencana yang telah ditentukan.

d. Kepuasan, adalah sikap para karyawan yang menunjang tingkat kepuasan terhadap tugasnya, lingkungan perusahaan, serta jaminanjaminan yang diperolehnya meliputi tingkat kepuasan terhadap tugas dan pekerjaannya.

\section{Motivasi}

Menurut Siagian (2008:138), indikator motivasi sebagai berikut:

a. Daya pendorong, yaitu semacam naluri tetapi hanya suatu dorongan kekuatan yang luas terhadap suatu arah yang umum.

b. Kemauan, yaitu dorongan yang dimiliki seseorang untuk melakukan sesuatu karena ada pengaruh dari luar mereka.

c. Kerelaan, yaitu suatu bentuk persetujuan atas adanya permintaan orang lain agar dirinya mengabulkan permintaan tersebut. 
d. Ketrampilan, yaitu kemampuan melakukan pola-pola tingkah laku yang kompleks dan tersusun rapi secara mulus dan sesuai dengan keadaan untuk mencapai hasil tertentu.

e. Tanggung jawab, yaitu sebagai suatu akibat lebih lanjut dari pelaksanaan peranan, baik peranan itu merupakan hak maupun kewajiban ataupun kekuasaan.

f. Kewajiban, yaitu sesuatu yang harus dilaksanakan atau dilakukan atas sesuatu yang dibebankan kepadanya

g. Tujuan, yaitu merupakan pernyataan tentang keadaan yang diinginkan dimana organisasi atau perusahaan bermaksud untuk mewujudkan pencapaian tujuannya.

Menurut Sofyandi dan Garniwa $(2007 ; 102)$ indikator motivasi sebagai berikut:

a. Kebutuhan fisiologis, merupakan hirarki kebutuhan manusia yang paling dasar yang merupakan kebutuhan untuk dapat hidup seperti makan, minum, perumahan, oksigen, tidur dan sebagainya

b. Kebutuhan rasa aman

Apabila kebutuhan fisiologis relatif sudah terpuaskan, maka muncul kebutuhan yang kedua yaitu kebutuhan rasa aman.

c. Kebutuhan sosial

Jika kebutuhan fisiologis dan rasa aman telah terpuaskan secara minimal, maka akan muncul kebutuhan sosial, yaitu kebutuhan untuk persahabatan, afiliasi dan interaksi yang lebih erat dengan orang lain.

d. Kebutuhan aktualisasi diri

Aktualisasi diri merupakan hirarki kebutuhan Maslow yang paling tinggi. Aktualisasi diri berkaitan dengan proses pengembangan potensi yang sesungguhnya dari seseorang.

\section{Kinerja Karyawan}

Menurut Sutrisno $(2009 ; 152)$ ada enam indikator dari kinerja yaitu:

a. Hasil kerja, meliputi tingkat kuantitas maupun kualitas yang telah dihasilkan dan sejauh mana pengawasan dilakukan

b. Pengetahuan pekerjaan, meliputi tingkat pengetahuan yang terkait dengan tugas pekerjaan yang akan berpengaruh langsung terhadap kuantitas dan kualitas dari hasil kerja

c. Inisiatif

Tingkat inisiatif selama melaksanakan tugas pekerjaan khususnya dalam hal penanganan masalah-masalah yang timbul 
d. Kecekatan Mental

Tingkat kemampuan dan kecepatan dalam menerima instruksi kerja dan menyesuaikan dengan cara kerja serta situasi kerja yang ada.

e. Sikap

Tingkat semangat kerja serta sikap positif dalam melaksanakan tugas pekerjaan

Menurut Robbins (2006;260) ada enam indikator untuk mengukur kinerja karyawan secara individu yaitu:

a. Kualitas

Kualitas kerja diukur dari persepsi karyawan terhadap kualitas pekerjaan yang dihasilkan serta kesempurnaan tugas terhadap ketrampilan dan kemampuan karyawan

b. Kuantitas

Merupakan jumlah yang dihasilkan dinyatakan dalam istilah seperti jumlah unit, jumlah siklus aktivitas yang diselesaikan

c. Ketepatan Waktu

Merupakan tingkat aktivitas diselesaikan pada awal waktu yang dinyatakan, dilihat dari sudut koordinasi dengan hasil output serta memaksimalkan waktu yang tersedia untuk aktivitas lain

d. Efektivitas

Merupakan tingkat penggunaan sumber daya organisasi (tenaga, uang, teknologi, bahan baku) dimaksimalkan dengan maksud menaikkan hasil dari setiap unit dalam penggunaan sumber daya

e. Kemandirian

Merupakan suatu tingkat dimana karyawan mempunyai komitmen kerja dengan instansi dan tanggung jawab karyawan terhadap kantor

\section{METODOLOGI PENELITIAN}

\section{Populasi dan Sampel}

Populasi dalam penelitian ini adalah karyawan bagian Sumber Daya Manusia yang terdapat pada empat distrik yaitu Distrik Rayon Utama, Distrik Rayon Selatan, Distrik Tebu Tembakau dan Tanjung Garbus pada PT.Perkebunan Nusantara II Medan yang berjumlah 140 orang. Sampel diambil dengan menggunakan rumus Slovin (Sunyoto, 2012;16) yaitu:

$$
n=\frac{N}{1+N e^{2}}
$$




$$
\begin{gathered}
n=\frac{140}{1+\left(140 \times 0,1^{2}\right)} \\
n=58,33=58
\end{gathered}
$$

Penarikan sampel dari setiap Distrik diperoleh dengan menggunakan sampling fraction per cluster seperti ditunjukkan dalam tabel berikut:

Tabel 2.

Penarikan sampel dengan sampling fraction per cluster

\begin{tabular}{|l|l|l|l|}
\hline No & Kantor Cabang & $\begin{array}{l}\text { Jumlah } \\
\text { Populasi }\end{array}$ & Jumlah Sampel \\
\hline 1 & Distrik Rayon Utara & 37 & $(37 / 140) \times 58=15$ orang \\
\hline 2 & Distrik Rayon Selatan & 30 & $(30 / 140) \times 58=12$ orang \\
\hline 3 & Distrik Tebu Tembakau & 38 & $(38 / 140)$ x 58=16 orang \\
\hline 4 & Tanjung Garbus & 35 & $(35 / 140)$ x 58=15 orang \\
\hline & Total & 140 & 58 orang \\
\hline
\end{tabular}

Sumber: PTPN II Medan

\section{Operasionalisasi Variabel}

Tabel. 3.

Operasionalisasi variabel dalam penelitian ini dapat dilihat pada tabel berikut:

\begin{tabular}{|l|l|l|l|}
\hline Variabel & Definisi Operasional & Indikator & Skala \\
\hline Pengembangan & Pengembangan karir & 1. Keadilan karir & Likert \\
Karir $\left(\mathrm{X}_{1}\right)$ & adalah proses & 2. Perhatian & \\
& peningkatan kemampuan & penyelia & \\
& kerja individu yang & 3. Kesempatan & \\
& dicapai dalam rangka & 4. Minat & \\
& mencapai karir yang & 5. Kepuasan & \\
& diinginkan & karir & \\
\hline Semangat & Semangat kerja adalah & 1. Absensi & \\
Kerja $\left(\mathrm{X}_{2}\right)$ & kemampuan atau & 2. Kerja sama & \\
& kemauan setiap individu & 3. Kepuasan & \\
& atau sekelompok orang & kerja & \\
& untuk saling bekerja & 4. Sikap dan & \\
& sama dengan giat dan & tingkah laku & \\
& disiplin serta penuh rasa & 5. Disiplin & \\
\hline
\end{tabular}




\begin{tabular}{|c|c|c|c|}
\hline Variabel & Definisi Operasional & Indikator & Skala \\
\hline & $\begin{array}{l}\text { tanggung jawab disertai } \\
\text { kesukarelaan dan } \\
\text { kesediaannya untuk } \\
\text { mencapai tujuan } \\
\text { organisasi. }\end{array}$ & & \\
\hline Motivasi $\left(\mathrm{X}_{3}\right)$ & $\begin{array}{l}\text { Motivasi merupakan } \\
\text { suatu keberhasilan dalam } \\
\text { mengarahkan karyawan } \\
\text { dan organisasi agar mau } \\
\text { bekerja secara berhasil } \\
\text { dan mencapai tujuannya }\end{array}$ & $\begin{array}{l}\text { 1. Daya } \\
\text { pendorong } \\
\text { 2. Kemauan } \\
\text { 3. Kerelaan } \\
\text { 4. Ketrampilan } \\
\text { 5. Tanggung } \\
\text { jawab }\end{array}$ & \\
\hline $\begin{array}{l}\text { Kinerja } \\
\text { Karyawan (Y) }\end{array}$ & $\begin{array}{l}\text { Kinerja merupakan hasil } \\
\text { kerja yang dicapai } \\
\text { seseorang dalam } \\
\text { melaksanakan pekerjaan } \\
\text { sesuai dengan tugas dan } \\
\text { tanggung jawab yang } \\
\text { diberikan kepadanya }\end{array}$ & $\begin{array}{l}\text { 1. Hasil kerja } \\
\text { 2. Pengetahuan } \\
\text { pekerjaan } \\
\text { 3. Inisiatif } \\
\text { 4. Kecekatan } \\
\text { mental } \\
\text { 5. Sikap }\end{array}$ & \\
\hline
\end{tabular}

\section{Teknik Pengumpulan Data}

Teknik pengumpulan data yang digunakan dalam penelitian ini adalah sebagai berikut:

a. Kuesioner, yaitu pengumpulan data dengan cara membagikan angket kepada responden dengan mencantumkan beberapa alternatif jawaban.

b. Dokumentasi, pengumpulan data dari dokumen yang dimiliki PT.Perkebunan Nusantara II Medan

\section{Metode Analisis Data}

Metode analisis data yang digunakan dalam penelitian ini adalah metode analisis regresi linier berganda dengan persamaan regresi berganda sebagai berikut:

$$
\mathrm{Y}=\mathrm{A}+\mathrm{B}_{1} \mathrm{X}_{1}+\mathrm{B}_{2} \mathrm{X}_{2}+\mathrm{B}_{3} \mathrm{X}_{3}+\mathrm{e}_{\mathrm{i}}
$$

Dimana: $\mathrm{Y}=$ variabel terikat (Kinerja karyawan)

$\mathrm{X}_{1}=$ Variabel bebas 1 (Pengembangan karir) 


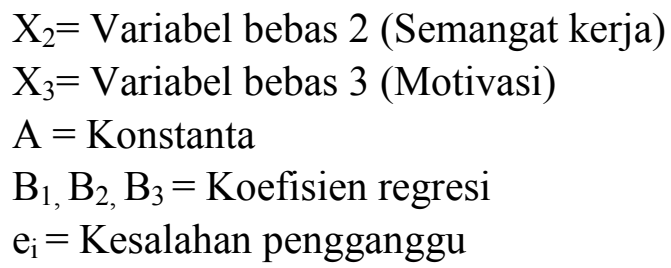

Untuk menguji pengaruh pengembangan karir, semangat kerja dan motivasi terhadap kinerja karyawan, dilakukan uji hipotesa baik secara parsial maupun secara simultan.

Uji Hipotesa Secara Parsial (Uji t)

Langkah - langkah pengujian:

- Rumusan hipotesa:

$\mathrm{H}_{0}: \mathrm{B}_{1}=\mathrm{B}_{2}=\mathrm{B}_{3} \leq 0$, artinya pengembangan karir, semangat kerja dan motivasi tidak

berpengaruh positif dan signifikan secara parsial terhadap kinerja karyawan pada PT.Perkebunan Nusantara II Medan.

$\mathrm{H}_{\mathrm{a}}: \mathrm{B}_{1}=\mathrm{B}_{2}=\mathrm{B}_{3}>0$, artinya pengembangan karir, semangat kerja dan motivasi

berpengaruh positif dan signifikan secara parsial terhadap kinerja karyawan pada PT.Perkebunan Nusantara II Medan.

- Menetukan tingkat signifikansi

- Uji Statistik : Uji t dengan rumus sebagai berikut: $\mathrm{t}=\frac{b}{\mathrm{~S} b}$

- Kriteria pengambilan keputusan:

$H_{o}$ ditolak jika $t_{\text {hit }} \geq t_{\text {tab }}$ atau jika nilai sig. $\leq \alpha$

$\mathrm{H}_{\mathrm{o}}$ tidak ditolak jika $\mathrm{t}_{\text {hit }}<\mathrm{t}_{\text {tab }}$ atau jika nilai sig. $>\alpha$

- Keputusan: $\mathrm{H}_{\mathrm{o}}$ diterima atau ditolak

Koefisien Determinasi $\left(\mathrm{R}^{2}\right)$.

Koefisien Determinasi $\left(\mathrm{R}^{2}\right)$ merupakan proporsi variabel bebas yang mampu menjelaskan variasi dari variabel terikat. Nilai $\mathrm{R}^{2}$ antara nol dan satu. 


\section{PEMBAHASAN}

\section{Analisis Deskripsi Variabel}

Penjelasan Responden Terhadap Pengembangan Karir

Tabel 8.

Penjelasan responden atas pernyataan menyangkut Pengembangan Karir

\begin{tabular}{|c|c|c|c|c|c|c|c|c|c|c|c|c|c|}
\hline No & Indikator & \multicolumn{10}{|c|}{ Kategori } & \multirow[t]{2}{*}{ Total } & $\%$ \\
\hline \multirow{3}{*}{1} & \multirow{3}{*}{$\begin{array}{l}\text { Pimpinan selalu } \\
\text { memberikan sikap } \\
\text { yang adil terhadap } \\
\text { karyawan dalam } \\
\text { hal pengembangan } \\
\text { karir karyawan }\end{array}$} & \multicolumn{2}{|c|}{ SSS } & \multicolumn{2}{|c|}{ SS } & \multicolumn{2}{|c|}{$\mathrm{S}$} & \multicolumn{2}{|c|}{ KS } & \multicolumn{2}{|c|}{ TSSS } & & \multirow{3}{*}{100} \\
\hline & & $\mathrm{Fr}$ & $\%$ & Fr & $\%$ & $\mathrm{Fr}$ & $\%$ & $\mathrm{Fr}$ & $\%$ & $\mathrm{Fr}$ & $\%$ & \multirow[t]{2}{*}{58} & \\
\hline & & 24 & $\begin{array}{l}4 \\
1\end{array}$ & 25 & 43 & 9 & 16 & 0 & 0 & 0 & 0 & & \\
\hline \multirow[t]{3}{*}{2} & \multirow{3}{*}{$\begin{array}{l}\text { Penyelia selalu } \\
\text { memotivasi } \\
\text { karyawan dalam } \\
\text { mengembangkan } \\
\text { karir }\end{array}$} & \multicolumn{2}{|c|}{ SSS } & \multicolumn{2}{|c|}{ SS } & \multicolumn{2}{|c|}{$\mathrm{S}$} & \multicolumn{2}{|c|}{ KS } & \multicolumn{2}{|c|}{ TSSS } & \multirow{3}{*}{58} & \multirow{3}{*}{100} \\
\hline & & $\mathrm{Fr}$ & $\%$ & $\mathrm{Fr}$ & $\%$ & Fr & $\%$ & $\mathrm{Fr}$ & $\%$ & Fr & $\%$ & & \\
\hline & & 27 & 47 & 29 & 50 & 2 & 3 & 0 & 0 & 0 & 0 & & \\
\hline \multirow[t]{3}{*}{3} & \multirow{3}{*}{$\begin{array}{l}\text { Seluruh karyawan } \\
\text { harus memiliki } \\
\text { kesadaran tentang } \\
\text { kesempatan untuk } \\
\text { mengembangkan } \\
\text { karir yang lebih baik } \\
\text { lagi }\end{array}$} & \multicolumn{2}{|c|}{ SSS } & \multicolumn{2}{|c|}{ SS } & \multicolumn{2}{|c|}{ S } & \multicolumn{2}{|c|}{ KS } & \multicolumn{2}{|c|}{ TSSS } & \multirow[t]{3}{*}{58} & \multirow[t]{3}{*}{100} \\
\hline & & $\mathrm{Fr}$ & $\%$ & Fr & $\%$ & $\mathrm{Fr}$ & $\%$ & Fr & $\%$ & $\mathrm{Fr}$ & $\%$ & & \\
\hline & & 20 & 34 & 29 & 50 & 8 & 14 & 1 & 2 & 0 & 0 & & \\
\hline \multirow[t]{3}{*}{4} & \multirow{3}{*}{$\begin{array}{l}\text { Kesempatan untuk } \\
\text { mengembangkan } \\
\text { karir dapat } \\
\text { menambah semangat } \\
\text { karyawan untuk } \\
\text { bekerja lebih baik }\end{array}$} & \multicolumn{2}{|c|}{ SSS } & \multicolumn{2}{|c|}{ SS } & \multicolumn{2}{|c|}{ S } & & & & SS & & \\
\hline & & $\mathrm{Fr}$ & $\%$ & $\mathrm{Fr}$ & $\%$ & $\mathrm{Fr}$ & $\%$ & $\mathrm{Fr}$ & $\%$ & $\mathrm{Fr}$ & $\%$ & & \\
\hline & & 23 & 40 & 30 & 52 & 5 & 8 & 0 & 0 & 0 & 0 & & \\
\hline 5 & Kesempatan & & & & $\mathrm{S}$ & & & & & & SS & & \\
\hline & $\begin{array}{l}\text { pengembangan karir } \\
\text { menjadikan karyawan }\end{array}$ & $\mathrm{Fr}$ & $\%$ & $\mathrm{Fr}$ & $\%$ & $\mathrm{Fr}$ & $\%$ & Fr & $\%$ & Fr & $\%$ & 58 & 100 \\
\hline & $\begin{array}{l}\text { merasa puas dalam } \\
\text { mengerjakan } \\
\text { tanggung jawabnya }\end{array}$ & 25 & 43 & 26 & 45 & 7 & 12 & 0 & 0 & 0 & 0 & & \\
\hline
\end{tabular}

Sumber : Data Primer Diolah

Dari tabel 8 dapat dilihat bahwa pernyataan tentang "Pimpinan selalu memberikan sikap yang adil terhadap karyawan dalam hal pengembangan karir karyawan", $41 \%$ menjawab sangat setuju sekali, $43 \%$ menjawab sangat setuju dan $16 \%$ menjawab setuju.Hal ini menunjukkan bahwa pimpinan bersikap adil terhadap karyawan dalam hal pengembangan karir karyawan.

Pernyataan tentang "penyelia selalu memotivasi karyawan dalam mengembangkan karir", $47 \%$ menjawab sangat setuju sekali, 50\% menjawab sangat setuju dan ada 3\% menjawab setuju. Hasil tersebut menunjukkan bahwa penyelia selalu memotivasi karyawan dalam mengembangkan karir, artinya penyelia sangat peduli dengan pengembangan karir karyawan

Pernyataan tentang "Seluruh karyawan harus memiliki kesadaran tentang kesempatan untuk mengembangkan karir yang lebih baik lagi", $34 \%$ menjawab sangat setuju sekali dan 50\% menjawab sangat setuju, $14 \%$ jawab menjawab setuju dan $2 \%$ menjawab kurang setuju. 
Pernyataan tentang "Kesempatan untuk mengembangkan karir dapat menambah semangat karyawan untuk bekerja lebih baik" $40 \%$ menjawab sangat setuju sekali, 52\% menjawab sangat setuju, dan $8 \%$ menjawab setuju. Artinya, manajemen perusahaan perlu memberi perhatian lebih lagi terhadap pengambangan karir karyawan karena hal tersebut dapat menambah semangat karyawan untuk bekerja lebih baik.

Pernyataan tentang "Kesempatan pengembangan karir menjadikan karyawan merasa puas dalam mengerjakan tanggung jawabnya", 43\% menjawab sangat setuju sekali, 45\% menjawab sangat setuju, dan $12 \%$ menjawab setuju. Artinya bahwa perusahaan perlu memperhatikan kesempatan pengembangan karir bagi karyawan, dimana hal tersebut dapat memberikan kepuasan dalam melaksanakan tugas yang pada akhirnya akan meningkatkan kinerja karyawan.

\section{Penjelasan Responden Terhadap Semangat Kerja}

Tabel 9.

Penjelasan responden atas pernyataan menyangkut Semangat Kerja

\begin{tabular}{|c|c|c|c|c|c|c|c|c|c|c|c|c|c|}
\hline $\mathrm{N}$ & Indikator & \multicolumn{10}{|c|}{ Kategori } & To & $\%$ \\
\hline \multirow{3}{*}{1} & \multirow{3}{*}{$\begin{array}{l}\text { Atasan mengawasi } \\
\text { kehadiran dan } \\
\text { mewajibkan } \\
\text { karyawan mengisi } \\
\text { daftar kehadiran }\end{array}$} & \multicolumn{2}{|c|}{ SSS } & \multicolumn{2}{|c|}{ SS } & \multicolumn{2}{|c|}{ S } & \multicolumn{2}{|c|}{ KS } & \multicolumn{2}{|c|}{ TSSS } & \multirow{3}{*}{58} & \multirow{3}{*}{100} \\
\hline & & $\mathrm{Fr}$ & $\%$ & $\mathrm{Fr}$ & $\%$ & $\mathrm{Fr}$ & $\%$ & $\mathrm{Fr}$ & $\%$ & $\mathrm{Fr}$ & $\%$ & & \\
\hline & & 31 & 53 & 17 & 29 & 9 & 16 & 1 & 2 & 0 & 0 & & \\
\hline \multirow[t]{3}{*}{2} & \multirow{3}{*}{$\begin{array}{l}\text { Karyawan selalu } \\
\text { menaati peraturan } \\
\text { yang ditetapkan } \\
\text { perusahaan }\end{array}$} & \multicolumn{2}{|c|}{ SSS } & \multicolumn{2}{|c|}{ SS } & \multicolumn{2}{|c|}{$\mathrm{S}$} & \multicolumn{2}{|c|}{$\mathrm{KS}$} & \multicolumn{2}{|c|}{ TSSS } & \multirow{3}{*}{58} & \multirow{3}{*}{100} \\
\hline & & $\mathrm{Fr}$ & $\%$ & $\mathrm{Fr}$ & $\%$ & $\mathrm{Fr}$ & $\%$ & $\mathrm{Fr}$ & $\%$ & $\mathrm{Fr}$ & $\%$ & & \\
\hline & & 22 & 38 & 29 & 50 & 7 & 12 & 0 & 0 & 0 & 0 & & \\
\hline \multirow[t]{3}{*}{3} & \multirow{3}{*}{$\begin{array}{l}\text { Karyawan mengikuti } \\
\text { standar kerja yang } \\
\text { ditetapkan perusahaan } \\
\text { dan melakukan } \\
\text { pekerjaan sebaik - } \\
\text { baiknya }\end{array}$} & \multicolumn{2}{|c|}{ SSS } & \multicolumn{2}{|c|}{ SS } & \multicolumn{2}{|c|}{$\mathrm{S}$} & \multicolumn{2}{|c|}{$\mathrm{KS}$} & \multicolumn{2}{|c|}{ TSSS } & \multirow[t]{3}{*}{58} & \multirow[t]{3}{*}{100} \\
\hline & & $\mathrm{Fr}$ & $\%$ & $\mathrm{Fr}$ & $\%$ & $\mathrm{Fr}$ & $\%$ & $\mathrm{Fr}$ & $\%$ & $\mathrm{Fr}$ & $\%$ & & \\
\hline & & 27 & 47 & 27 & 47 & 4 & 6 & 0 & 0 & 0 & 0 & & \\
\hline \multirow[t]{3}{*}{4} & \multirow{3}{*}{$\begin{array}{l}\text { Karyawan selalu } \\
\text { waspada dan } \\
\text { bertanggungjawab } \\
\text { atas semua pekerjaan } \\
\text { yang diberikan atasan }\end{array}$} & \multicolumn{2}{|c|}{ SSS } & \multicolumn{2}{|c|}{ SS } & \multicolumn{2}{|c|}{ S } & \multicolumn{2}{|c|}{$\mathrm{KS}$} & & & 58 & \\
\hline & & $\mathrm{Fr}$ & $\%$ & $\mathrm{Fr}$ & $\%$ & $\mathrm{Fr}$ & $\%$ & $\mathrm{Fr}$ & $\%$ & $\mathrm{Fr}$ & $\%$ & & 100 \\
\hline & & 26 & 45 & 24 & 41 & 8 & 14 & 0 & 0 & 0 & 0 & & \\
\hline 5 & Karyawan selalu & & & & $\mathrm{S}$ & & & & & & & 58 & 100 \\
\hline & $\begin{array}{l}\text { bekerja etis dan } \\
\text { menoikuti instruksi }\end{array}$ & $\mathrm{Fr}$ & $\%$ & $\mathrm{Fr}$ & $\%$ & $\mathrm{Fr}$ & $\%$ & $\mathrm{Fr}$ & $\%$ & $\mathrm{Fr}$ & $\%$ & & \\
\hline & atasan & 25 & 43 & 26 & 45 & 7 & 12 & 0 & 0 & 0 & 0 & & \\
\hline
\end{tabular}

Sumber: Data Primer diolah

Dari tabel 9 dapat dilihat bahwa pernyataan tentang "Atasan mengawasi kehadiran dan mewajibkan karyawan mengisi daftar kehadiran", 53\% menjawab sangat setuju sekali, 29\% menjawab sangat setuju, $16 \%$ menjawab setuju dan $2 \%$ menjawab tidak setuju. 
Pernyataan tentang "Karyawan selalu menaati peraturan yang ditetapkan perusahaan", $38 \%$ menjawab sangat setuju sekali, $50 \%$ menjawab sangat setuju, dan $12 \%$ menjawab setuju. Artinya bahwa pada umumnya karyawan mematuhi aturan - aturan yang berlaku pada saat melaksanakan tugas.

Pernyataan tentang "Karyawan mengikuti standar kerja yang ditetapkan perusahaan dan melakukan pekerjaan sebaik -baiknya", $47 \%$ menjawab sangat setuju sekali, $47 \%$ menjawab sangat setuju, dan $6 \%$ menjawab setuju.

Pernyataan tentang "Karyawan selalu waspada dan bertanggungjawab atas semua pekerjaan yang diberikan atasan", 45\%menjawab sangat setuju sekali, $41 \%$ menjawab sangat setuju, dan $14 \%$ menjawab setuju. Artinya bahwa pada umumnya karyawan selalu waspada dan bertanggung jawab pada saat melaksanakan tugas masingmasing.

Pernyataan tentang "Karyawan selalu bekerja etis dan mengikuti instruksi atasan", 53\%menjawab sangat setuju sekali, 33\% menjawab sangat setuju, dan 14\% menjawab setuju. Artinya bahwa pada umumnya karyawan sudah bekerja etis dan selalu mengikuti instruksi dari atasan pada saat melaksanakan tugas masing-masing.

\section{Penjelasan Responden Terhadap Motivasi}

Tabel 10.

Penjelasan responden atas pernyataan menyangkut Motivasi

\begin{tabular}{|c|c|c|c|c|c|c|c|c|c|c|c|c|c|}
\hline $\mathrm{N}$ & Indikator & \multicolumn{10}{|c|}{ Kategori } & To & $\%$ \\
\hline \multirow{3}{*}{1} & \multirow{3}{*}{$\begin{array}{l}\text { Wewenang dan } \\
\text { tanggung jawab } \\
\text { memotivasi saya } \\
\text { dalam } \\
\text { melaksanakan tugas }\end{array}$} & \multicolumn{2}{|c|}{ SSS } & \multicolumn{2}{|c|}{ SS } & \multicolumn{2}{|c|}{$\mathrm{S}$} & \multicolumn{2}{|c|}{ KS } & \multicolumn{2}{|c|}{ TSSS } & \multirow{3}{*}{58} & \multirow{3}{*}{100} \\
\hline & & $\mathrm{Fr}$ & $\%$ & $\mathrm{Fr}$ & $\%$ & $\mathrm{Fr}$ & $\%$ & $\mathrm{Fr}$ & $\%$ & $\mathrm{Fr}$ & $\%$ & & \\
\hline & & 30 & 52 & 23 & 40 & 5 & 8 & 0 & 0 & 0 & 0 & & \\
\hline \multirow[t]{3}{*}{2} & \multirow{3}{*}{$\begin{array}{l}\text { Saya bekerja atas } \\
\text { kesadaran sendiri }\end{array}$} & \multicolumn{2}{|c|}{ SSS } & \multicolumn{2}{|c|}{ SS } & \multicolumn{2}{|c|}{$\mathrm{S}$} & \multicolumn{2}{|c|}{ KS } & \multicolumn{2}{|c|}{ TSSS } & \multirow{3}{*}{58} & \multirow{3}{*}{100} \\
\hline & & Fr & $\%$ & $\mathrm{Fr}$ & $\%$ & Fr & $\%$ & Fr & $\%$ & $\mathrm{Fr}$ & $\%$ & & \\
\hline & & 20 & 34 & 23 & 40 & 9 & 16 & 6 & 10 & 0 & 0 & & \\
\hline \multirow[t]{3}{*}{3} & \multirow{3}{*}{$\begin{array}{l}\text { Saya bersedia } \\
\text { bekerja diluar jam } \\
\text { kerja demi } \\
\text { menyelesaikan } \\
\text { tugas }\end{array}$} & \multicolumn{2}{|c|}{ SSS } & \multicolumn{2}{|c|}{ SS } & \multicolumn{2}{|c|}{ S } & \multicolumn{2}{|c|}{ KS } & \multicolumn{2}{|c|}{ TSSS } & \multirow[t]{3}{*}{58} & \multirow[t]{3}{*}{100} \\
\hline & & $\mathrm{Fr}$ & $\%$ & $\mathrm{Fr}$ & $\%$ & $\mathrm{Fr}$ & $\%$ & $\mathrm{Fr}$ & $\%$ & $\mathrm{Fr}$ & $\%$ & & \\
\hline & & 22 & 38 & 17 & 29 & 17 & 28 & 2 & 3 & 0 & 0 & & \\
\hline \multirow[t]{3}{*}{4} & \multirow{3}{*}{$\begin{array}{l}\text { Tugas yang } \\
\text { diberikan memberi } \\
\text { kesempatan untuk } \\
\text { menerapkan } \\
\text { ketrampilan saya }\end{array}$} & \multicolumn{2}{|c|}{ SSS } & \multicolumn{2}{|c|}{ SS } & \multicolumn{2}{|c|}{$\mathrm{S}$} & \multicolumn{2}{|c|}{ KS } & & & 58 & \\
\hline & & $\mathrm{Fr}$ & $\%$ & $\mathrm{Fr}$ & $\%$ & $\mathrm{Fr}$ & $\%$ & $\mathrm{Fr}$ & $\%$ & Fr & $\%$ & & 100 \\
\hline & & 30 & 52 & 15 & 26 & 11 & 19 & 2 & 3 & 0 & 0 & & \\
\hline 5 & Saya melaksanakan & & & & S & & & & & & & 58 & 100 \\
\hline & pekerjaan sesuai & $\mathrm{Fr}$ & $\%$ & $\mathrm{Fr}$ & $\%$ & $\mathrm{Fr}$ & $\%$ & $\mathrm{Fr}$ & $\%$ & $\mathrm{Fr}$ & $\%$ & & \\
\hline & $\begin{array}{l}\text { pembagian tugas } \\
\text { yang saya terima }\end{array}$ & 29 & 50 & 19 & 33 & 9 & 15 & 1 & 2 & 0 & 0 & & \\
\hline
\end{tabular}

Sumber: Data Primer diolah 
Dari tabel 10 dapat dilihat bahwa pernyataan tentang "Wewenang dan tanggung jawab memotivasi saya dalam melaksanakan tugas", $52 \%$ menjawab sangat setuju sekali, 40\% menjawab sangat setuju, dan $8 \%$ menjawab setuju. Hal ini menunjukkan bahwa para karyawan pada umumnya merasa senang dengan wewenang dan tanggung jawab yang mereka terima, karena mampu memotivasi untuk melaksanakan tugas dengan lebih baik.

Pernyataan tentang "Saya bekerja atas kesadaran sendiri", $34 \%$ menjawab sangat setuju sekali, 40\% menjawab sangat setuju, 16\% menjawab setuju dan 10\% menjawab tidak setuju. Artinya bahwa pada umumnya responden sudah melaksanakan tugasnya atas dasar kesadaran masing-masing, dimana kondisi yang demikian akan sangat mendukung untuk kinerja yang baik.

Pernyataan tentang "Saya bersedia bekerja diluar jam kerja demi menyelesaikan tugas", 38\%menjawab sangat setuju sekali, $28 \%$ menjawab sangat setuju, 29\% menjawab setuju dan 3\% menjawab tidak setuju. Artinya bahwa pada umumnya responden sudah mempunyai kesadaran dan tanggung jawab yang cukup tinggi akan pekerjaannya, dimana mereka bersedia bekerja di luar jam kerja apabila dibutuhkan perusahaan demi mencapai target yang telah ditetapkan.

Pernyataan tentang "Tugas yang diberikan memberi kesempatan untuk menerapkan ketrampilan saya", 52\% menjawab sangat setuju sekali, $26 \%$ menjawab sangat setuju, 19\% menjawab setuju dan 3\% menjawab tidak setuju. Artinya bahwa pada umumnya responden merasa puas atas tugas yang mereka terima karena memberi kesempatan untuk menerapkan ketrampilan yang mereka miliki. Dengan kata lain, tugas yang diberikan kepada karyawan sudah sesuai dengan latar belakang pendidikan dan ketrampilan yang mereka miliki, dimana hal demikian akan sangat memotivasi untuk dapat mencapai kinerja yang baik.

Pernyataan tentang "Saya melaksanakan pekerjaan sesuai pembagian tugas yang saya terima

", 50\% menjawab sangat setuju sekali, 33\% menjawab sangat setuju, 15\% menjawab setuju dan 2\% menjawab tidak setuju. Artinya bahwa pada umumnya responden memahami batas-batas tugas dan wewenang masingmasing, sehingga tidak terdapat tumpang tindih dalam melaksanakan tugas dan setiap responden fokus ke tugasnya. 


\section{Penjelasan Responden Terhadap Kinerja Karyawan}

Tabel 11.

Penjelasan responden atas pernyataan menyangkut Kinerja Karyawan

\begin{tabular}{|c|c|c|c|c|c|c|c|c|c|c|c|c|c|}
\hline No & Indikator & \multicolumn{10}{|c|}{ Kategori } & Total & $\%$ \\
\hline \multirow{3}{*}{1} & \multirow{3}{*}{$\begin{array}{l}\text { Karyawan selalu } \\
\text { berusaha } \\
\text { memperoleh hasil } \\
\text { kerja yang lebih } \\
\text { baik }\end{array}$} & \multicolumn{2}{|c|}{ SSS } & \multicolumn{2}{|c|}{ SS } & \multicolumn{2}{|c|}{$\mathrm{S}$} & \multicolumn{2}{|c|}{ KS } & \multicolumn{2}{|c|}{ TSSS } & \multirow{3}{*}{58} & \multirow{3}{*}{100} \\
\hline & & $\mathrm{Fr}$ & $\%$ & $\mathrm{Fr}$ & $\%$ & $\mathrm{Fr}$ & $\%$ & Fr & $\%$ & $\mathrm{~F}$ & $\%$ & & \\
\hline & & 26 & 45 & 30 & 52 & 2 & 3 & 0 & 0 & $\frac{1}{0}$ & 0 & & \\
\hline \multirow{4}{*}{2} & \multirow{4}{*}{$\begin{array}{l}\text { Kemampuan } \\
\text { karyawan } \\
\text { mendukung } \\
\text { pelaksanaan tugas } \\
\text { dengan baik }\end{array}$} & \multicolumn{2}{|c|}{ SSS } & \multicolumn{2}{|c|}{ SS } & \multicolumn{2}{|c|}{$\mathrm{S}$} & \multicolumn{2}{|c|}{ KS } & $\frac{T}{T S}$ & & \multirow{4}{*}{58} & \multirow{4}{*}{100} \\
\hline & & $\mathrm{Fr}$ & $\%$ & $\mathrm{Fr}$ & $\%$ & $\mathrm{Fr}$ & $\%$ & $\mathrm{Fr}$ & $\%$ & $\mathrm{Fr}$ & $\%$ & & \\
\hline & & & & & & & & & & & & & \\
\hline & & 30 & 52 & 22 & 38 & 6 & 10 & 0 & 0 & 0 & 0 & & \\
\hline \multirow[t]{3}{*}{3} & \multirow{3}{*}{$\begin{array}{l}\text { Diberi wewenang } \\
\text { bagi karyawan } \\
\text { dalam mengatasi } \\
\text { masalah pekerjaan }\end{array}$} & \multicolumn{2}{|c|}{ SSS } & \multicolumn{2}{|c|}{ SS } & \multicolumn{2}{|c|}{$\mathrm{S}$} & \multicolumn{2}{|c|}{ KS } & \multicolumn{2}{|c|}{ TSSS } & \multirow[t]{3}{*}{58} & \multirow[t]{3}{*}{100} \\
\hline & & $\mathrm{Fr}$ & $\%$ & $\mathrm{Fr}$ & $\%$ & $\mathrm{Fr}$ & $\%$ & $\mathrm{Fr}$ & $\%$ & $\mathrm{Fr}$ & $\%$ & & \\
\hline & & 26 & 45 & 30 & 52 & 2 & 3 & 0 & ) & 0 & 0 & & \\
\hline \multirow[t]{3}{*}{4} & \multirow{3}{*}{$\begin{array}{l}\text { Pengetahuan dan } \\
\text { kecekatan karyawan } \\
\text { dapat membantu } \\
\text { pimpinan dalam } \\
\text { mencapai tujuan } \\
\text { perusahaan }\end{array}$} & \multicolumn{2}{|c|}{ SSS } & \multicolumn{2}{|c|}{ SS } & \multicolumn{2}{|c|}{$\mathrm{S}$} & \multicolumn{2}{|c|}{$\mathrm{KS}$} & \multicolumn{2}{|c|}{ TSSS } & 58 & \\
\hline & & $\mathrm{Fr}$ & $\%$ & $\mathrm{Fr}$ & $\%$ & $\mathrm{Fr}$ & $\%$ & $\mathrm{Fr}$ & $\%$ & Fr & $\%$ & & 100 \\
\hline & & 25 & 43 & 24 & 41 & 9 & 16 & 0 & 0 & 0 & 0 & & \\
\hline 5 & Karyawan selalu & & & & $\mathrm{S}$ & & & & & & SS & 58 & 100 \\
\hline & $\begin{array}{l}\text { memberikan } \\
\text { pelayanan yang baik }\end{array}$ & $\mathrm{Fr}$ & $\%$ & Fr & $\%$ & Fr & $\%$ & Fr & $\%$ & Fr & $\%$ & & \\
\hline & kepada pelanggan & 30 & 52 & 19 & 33 & 9 & 16 & 0 & 0 & 0 & 0 & & \\
\hline
\end{tabular}

Sumber: Data Primer diolah

Dari tabel 11 dapat dilihat bahwa pernyataan tentang "Karyawan selalu berusaha memperoleh hasil kerja yang lebih baik", $45 \%$ menjawab sangat setuju sekali, 52\% menjawab sangat setuju, dan 3\% menjawab setuju. Hal ini menunjukkan bahwa para responden pada umumnya selalu berusaha untuk mencapai hasil kerja yang lebih baik.

Pernyataan tentang "Kemampuan karyawanmendukung pelaksanaantugas dengan baik

", 52\% menjawab sangat setuju sekali, 26\% menjawab sangat setuju, 19\% menjawab setuju dan 3\% menjawab tidak setuju. Artinya bahwa pada umumnya responden sudah ditempatkan pada bidang yang sesuai dengan kemampuannya sehingga kalau terjadi masalah dalam pekerjaan para karyawan memiliki kemampuan untuk mengatasinya dan pada akhirnya kinerja yang tinggi akan tercapai.

Pernyataan tentang "Diberi wewenang bagi karyawan dalam mengatasi masalah pekerjaan

", 45\% menjawab sangat setuju sekali, 52\% menjawab sangat setuju, 3\% menjawab setuju. Artinya bahwa pada umumnya responden merasa puas karena mereka diberi otonomi untuk mengatasi masalah yang mereka hadapi dalam pekerjaan dimana kebebasan seperti ini dapat mempeerbaiki hasil kerja yang dicapai karyawan. 
Pernyataan tentang "Pengetahuan dan kecekatan karyawan dapat membantu pimpinan dalam mencapai tujuan perusahaan", $43 \%$ menjawab sangat setuju sekali, $41 \%$ menjawab sangat setuju, $16 \%$ menjawab setuju. Artinya bahwa pada umumnya responden memiliki pengalaman dan kecerdasan yang tinggi sehingga mereka mampu membantu pimpinan dalam mengembangkan perusahaan.

Pernyataan tentang "Karyawan selalu memberikan pelayanan yang baik kepada pelanggan

", 52\% menjawab sangat setuju sekali, 32\% menjawab sangat setuju, 16\% menjawab setuju. Artinya bahwa pada umumnya responden sudah melaksanakan tugasnya dengan baik dalam kaitannya dengan pelayanan terhadap pelanggan. Dalam hal ini responden sudah menyadari pentingnya pelanggan bagi kelangsungan hidup perusahaan sehingga mereka melayani pelanggan dengan sikap yang ramah dan dengan komunikasi yang baik.

\section{Uji Vailiditas dan Uji Reliabilitas Secara Simultan} tabel berikut:

Hasil uji validitas dan relibilitas secara simultan disajikan pada Tabel 12.

Case Processing Summary

\begin{tabular}{|c|r|r|}
\hline & $\mathrm{N}$ & \multicolumn{1}{|c|}{$\%$} \\
\hline Cases Valid $^{\text {Excluded }}{ }^{\mathrm{a}}$ & 58 & 100.0 \\
Total & 0 & .0 \\
\hline
\end{tabular}

a. Listwise deletion based on all variables in the procedure

Sumber: Data primer diolah

Tabel 12 menunjukkan bahwa 58 jawaban responden, seluruhnya $(100 \%)$ sudah valid. Hasil uji reliabilitas secara simultan disajikan pada tabel berikut:

Tabel 13.

Reliability Statistics

\begin{tabular}{|r|rr|}
\hline \multicolumn{2}{|r|}{ Cronbach's Alpha } & \multicolumn{2}{c|}{ N of Items } \\
\hline & .890 & \\
\hline
\end{tabular}

Sumber: Data primer diolah

Dari Tabel 13 diketahui bahwa keduapuluh pernyataan dalam penelitian ini sudah reliabel, karena nilai cronbach's alpha 0,890>0,50. 
Selanjutnya disajikan hasil uji validitas dan reliabilitas secara simultan sebagai berikut:

Tabel 14.

Item-Total Statistics

\begin{tabular}{|c|c|c|c|c|}
\hline & $\begin{array}{l}\text { Corrected } \\
\text { Item-Total } \\
\text { Correlaton }\end{array}$ & Keterangan & $\begin{array}{l}\text { Cronbach } \\
\text { Alpha if Item } \\
\text { Deleted }\end{array}$ & Keterangan \\
\hline PK1 & .516 & Valid & .884 & Reliabel \\
\hline PK2 & .501 & Valid & .885 & Reliabel \\
\hline PK3 & .456 & Valid & .886 & Reliabel \\
\hline PK4 & .601 & Valid & .882 & Reliabel \\
\hline PK5 & .387 & Valid & .890 & Reliabel \\
\hline SK1 & .533 & Valid & .884 & Reliabel \\
\hline SK2 & .395 & Valid & .888 & Reliabel \\
\hline SK3 & .429 & Valid & .887 & Reliabel \\
\hline SK4 & .581 & Valid & .882 & Reliabel \\
\hline SK5 & .719 & Valid & .878 & Reliabel \\
\hline M1 & .375 & Valid & .888 & Reliabel \\
\hline M2 & .414 & Valid & .889 & Reliabel \\
\hline M3 & .462 & Valid & .887 & Reliabel \\
\hline M4 & .607 & Valid & .881 & Reliabel \\
\hline M5 & .525 & Valid & .884 & Reliabel \\
\hline KK1 & .549 & Valid & .884 & Reliabel \\
\hline KK2 & .697 & Valid & .879 & Reliabel \\
\hline KK3 & .431 & Valid & .894 & Reliabel \\
\hline KK4 & .628 & Valid & .881 & Reliabel \\
\hline KK5 & .744 & Valid & .877 & Reliabel \\
\hline
\end{tabular}

Sumber: Data primer diolah

Dari data pada Tabel 14 diketahui bahwa keduapuluh pernyataan penelitian pada PT.Perkebunan Nusantara II Medan, secara rata-rata sudah valid, karena nilai $r_{\text {hitung }}>0,30$. Dan seluruh Variabel penelitian sudah reliabel karena nilai cronbach's alpha if item $>0,50$.

\section{Hasil Uji Validitas dan Reliabilitas Secara Parsial}

Hasil uji validitas dan reliabilitas secara parsial pada variabel Pengembangan Karir $\left(\mathrm{X}_{1}\right)$ disajikan pada tabel berikut: 
Tabel 15.

Case Processing Summary

\begin{tabular}{|l|r|rr|}
\hline & $\mathrm{N}$ & \multicolumn{2}{|c|}{$\%$} \\
\hline Cases Valid & 58 & & 100.0 \\
& Excluded $^{\mathrm{a}}$ & 0 & .0 \\
$\quad$ Total & 58 & 100.0 \\
\hline
\end{tabular}

a. Listwise deletion based on all variables in the procedure Sumber: Data primer diolah

Dari data pada Tabel 15 dapat dilihat bahwa 58 jawaban responden $100 \%$ sudah valid. Hasil uji reliabilitas secara parsial pada variabel pengembangan karir disajikan pada tabel berikut:

Tabel 16.

Reliability Statistics

\begin{tabular}{|c|c|}
\hline Cronbach's Alpha & $\mathrm{N}$ of Items \\
\hline .674 & 5 \\
\hline
\end{tabular}

Sumber: Data primer diolah

Dari data pada Tabel 16 diketahui bahwa kelima pernyataan dalam penelitian ini sudah reliabel, karena cronbach's alpha 0,674 >0,50. Selanjutnya, disajikan hasil uji validitas dan reliabilitas secara parsial pada variabel pengembangan karir berikut ini:

Tabel 17.

Item - Total Statistics

\begin{tabular}{|l|r|r|r|r|}
\hline & $\begin{array}{l}\text { Corrected } \\
\text { Item-Total } \\
\text { Correlation }\end{array}$ & Keterangan & $\begin{array}{l}\text { Cronbach's } \\
\text { Alpha if } \\
\text { Item } \\
\text { Deleted }\end{array}$ & Keterangan \\
\hline Pengembangan_karir1 & .368 & Valid & .697 & Reliabel \\
Pengembangan_karir2 & .535 & Valid & .585 & Reliabel \\
Pengembangan_karir3 & .385 & Valid & .645 & Reliabel \\
Pengembangan_karir4 & .622 & Valid & .537 & Reliabel \\
Pengembangan_karir5 & .391 & Valid & .640 & Reliabel \\
\hline
\end{tabular}

Sumber: Data diolah dengan SPSS 
Dari data pada Tabel 17 dapat dilihat bahwa kelima pernyataan penelitian pada PT.Perkebunan Nusantara II Medan secara rata-rata sudah valid, karena $r_{\text {hitung }}>0,30$. Dan dari tabel 16 juga terlihat bahwa seluruh variabel penelitian sudah reliabel, karena nilai cronbach's alpha if item $>$ 0,50 .

Hasil uji validitas secara parsial pada variabel semangat kerja $\left(\mathrm{X}_{2}\right)$ disajikan pada tabel berikut:

Tabel 18.

Case Processing Summary

\begin{tabular}{|c|c|c|}
\hline & $\mathrm{N}$ & $\%$ \\
\hline Cases Valid & 58 & 100.0 \\
\hline Excluded $^{\mathrm{a}}$ & 0 & .0 \\
\hline Total & 58 & 100.0 \\
\hline
\end{tabular}

a. Listwise deletion based on all variables in the procedure

Sumber: Data primer diolah

Dari data pada Tabel 18 dapat dilihat bahwa dari 58 jawaban responden, $100 \%$ sudah valid. Hasil uji reliabilitas secara parsial pada variabel semangat kerja disajikan pada tabel berikut:

Tabel 19.

Reliability Statistics

\begin{tabular}{|lr|r|}
\hline \multicolumn{2}{|c|}{ Cronbach's Alpha } & N of Items \\
\hline & .758 & \\
\hline
\end{tabular}

Sumber: Data primer diolah

Dari data pada Tabel 19 dapat dilihat bahwa kelima pernyataan tentang variabel semangat kerja dalam penelitian ini sudah reliabel karena cronbach's alpha $(0,758)>0,50$. Selanjutya, disajikan hasil uji validitas dan reliabilitas secara parsial pada variabel semangat kerja pada tabel berikut.

Tabel 20.

Item Total Statistics

\begin{tabular}{|l|r|r|r|r|}
\hline & $\begin{array}{c}\text { Corrected } \\
\text { Item-Total } \\
\text { Correlation }\end{array}$ & Keterangan & $\begin{array}{c}\text { Cronbach's } \\
\text { Alpha if Item } \\
\text { Deleted }\end{array}$ & Keterangan \\
\hline Semangat_kerja1 & .479 & Valid & .737 & Reliabel \\
Semangat_kerja2 & .576 & Valid & .699 & Reliabel \\
Semangat_kerja3 & .513 & Valid & .721 & Reliabel \\
Semangat_kerja4 & .456 & Valid & .739 & Reliabel \\
Semangat_kerja5 & .628 & Valid & .677 & Reliabel \\
\hline
\end{tabular}

Sumber: data primer diolah 
Dari data pada Tabel 20 dapat dilihat bahwa kelima pernyataan tentang variabel semangat kerja dalam penelitian pada PT. Perkebunan Nusantara II Medan secara rata-rata sudah valid dan sudah reliabel karena nilai $\mathrm{r}_{\text {hitung }}>0,30$ dan nilai cronbach's alphaif item $>0,50$.

Hasil uji validitas secara parsial pada variabel Motivasi $\left(\mathrm{X}_{3}\right)$ disajikan pada tabel berikut:

Tabel 21.

Case Processing Summary

\begin{tabular}{|c|c|c|}
\hline & $\mathrm{N}$ & $\%$ \\
\hline Cases Valid & 58 & 100.0 \\
\hline Excluded $^{\mathrm{a}}$ & 0 & .0 \\
\hline Total & 58 & 100.0 \\
\hline
\end{tabular}

a. Listwise deletion based on all variables in the procedure

Sumber: Data primer diolah

Berdasarkan data pada Tabel 21 dapat dilihat bahwa dari 58 jawaban responden, $100 \%$ sudah valid. Hasil uji reliabilitas secara parsial pada variabel Motivasi $\left(\mathrm{X}_{3}\right)$ disajikan pada tabel berikut:

Tabel 22.

Reliabiliy Statistics

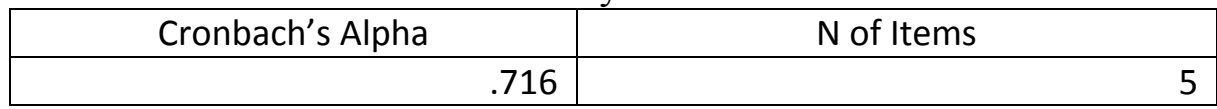

Sumber: Data primer diolah

Berdasarkan data pada Tabel 22 dapat dilihat bahwa kelima pernyataan tentang variabel motivasi dalam penelitian ini sudah reliabel, karena cronbach's alpha $(0,716)>0,50$. Selanjutnya disajikan hasil uji validitas dan reliabilitas secara parsial pada variabel motivasi pada tabel berikut.

Tabel 23.

Item-Total Statistics

\begin{tabular}{|l|r|r|r|r|}
\hline & $\begin{array}{c}\text { Corrected } \\
\text { Item-Total } \\
\text { Correlation }\end{array}$ & Keterangan & $\begin{array}{c}\text { Cronbach's } \\
\text { Alpha if Item } \\
\text { Deleted }\end{array}$ & Keterangan \\
\hline Motivasi1 & .386 & Valid & .723 & Reliabel \\
Motivasi2 & .416 & Valid & .688 & Reliabel \\
Motivasi3 & .439 & Valid & .675 & Reliabel \\
Motivasi4 & .591 & Valid & .608 & Reliabel \\
Motivasi5 & .631 & Valid & .597 & Reliabel \\
\hline
\end{tabular}

Sumber: Data primer diolah 
Berdasarkan data pada Tabel 23 dapat dilihat bahwa kelima pernyataan tentang motivasi dalam penelitian pada PT. Perkebunan Nusantara II Medan sudah valid dan sudah reliabel, karena $r_{\text {hitung }}>0,30$ dan cronbach's alpha if item $>0,50$.

Hasil uji validitas secara parsial pada variabel kinerja karyawan (Y) disajikan pada tabel berikut:

Tabel 24.

Case Processing Summary

\begin{tabular}{|c|c|c|}
\hline & $\mathrm{N}$ & $\%$ \\
\hline Cases Valid & 58 & 100.0 \\
\hline Excluded $^{\mathrm{a}}$ & 0 & .0 \\
\hline Total & 58 & 100.0 \\
\hline
\end{tabular}

a. Listwise deletion based on all variables in the procedure

Sumber: Data primer diolah

Dari data pada Tabel 24 dapat dilihat bahwa dari 58 jawaban responden, $100 \%$ sudah valid. Hasil uji reliabilitas secara parsial pada variabel kinerja karyawan (Y) disajikan pada tabel berikut:

Tabel 25.

Reliabiliy Statistics

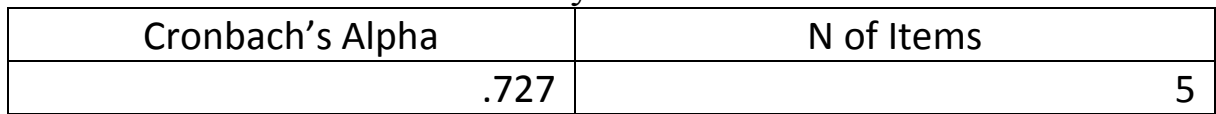

Sumber: Data primer diolah

Dari data pada Tabel 25 dapat dilihat bahwa kelima pernyataan tentang variabel kinerja karyawan dalam penelitian ini sudah reliabel, dimana cronbach's alpha $(0,727)>0,50$. Selanjutnya disajikan hasil uji validitas dan reliabilitas secara parsial pada variabel kinerja karyawan pada tabel berikut:

Tabel 26.

Item Total Statistics

\begin{tabular}{|l|r|r|r|r|}
\hline & $\begin{array}{c}\text { Corrected } \\
\text { Item-Total } \\
\text { Correlation }\end{array}$ & Keterangan & $\begin{array}{c}\text { Cronbach's } \\
\text { Alpha if Item } \\
\text { Deleted }\end{array}$ & Keterangan \\
\hline Kinerja_karyawan1 & .570 & Valid & .654 & Reliabel \\
Kinerja_karyawan 2 & .603 & Valid & .631 & Reliabel \\
Kinerja_karyawan 3 & .406 & Valid & .769 & Reliabel \\
Kinerja_karyawan 4 & .482 & Valid & .683 & Reliabel \\
Kinerja_karyawan 5 & .596 & Valid & .632 & Reliabel \\
\hline
\end{tabular}

Sumber: data primer diolah 
Berdasarkan data pada Tabel 26 dapat dilihat bahwa kelima pernyataan tentang kinerja karyawan pada penelitian di PT. Perkebunan Nusantara II Medan secara rata-rata sudah valid dan sudah reliabel, karena nilai $\mathrm{r}_{\text {hitung }}>0,30$ dan nilai cronbach's alpha if item $>0,50$.

\section{Pengujian Hipotesis}

a. Uji Simultan (Uji F)

Uji simultan dilakukan untuk mengetahui apakah terdapat pengaruh signifikan antara variabel bebas yaitu pengembangan karir, semangat kerja dan motivasi terhadap variabel terikat yaitu kinerja karyawan. Hal ini dapat diketahui dari perbandingan antara $F_{h i t u n g}$ dengan $F_{\text {tabel }}$ atau dengan membandingkan besarnya alpha dalam penelitian dengan besarnya nilai signifikansi yang ditunjukkan dalam tabel berikut (Out-put SPSS).

Tabel 27.

ANOVA $^{\mathrm{a}}$

\begin{tabular}{|c|c|c|c|c|c|}
\hline Model & $\begin{array}{l}\text { Sum of } \\
\text { Squares }\end{array}$ & $d f$ & $\begin{array}{l}\text { Mean } \\
\text { Square }\end{array}$ & $\mathrm{F}$ & Sig. \\
\hline 1 & 174.155 & 3 & 58.052 & 29.142 & $.000^{b}$ \\
\hline Regression & 107.569 & 54 & 1.992 & & \\
\hline $\begin{array}{l}\text { Residual } \\
\text { Total }\end{array}$ & 281.724 & 57 & & & \\
\hline
\end{tabular}

a. Dependent Variable: kinerja karyawan

b. Predictors: (Constant), motivasi, semangat kerja, pengembangan karir

Sumber: Data primer diolah

Dari data pada Tabel 27 dapat dilihat bahwa terdapat pengaruh yang signifikan antara variabel bebas yaitu pengembangan karir, semangat kerja dan motivasi terhadap variabel terikat yaitu kinerja karyawan pada PT. Perkebunan Nusantara II Medan. Hal tersebut dapat dilihat dari nilai $F_{\text {hitung }}(29,142)>$ nilai $F_{\text {tabel }}(2,78)$ dan nilai sig. $(0,000)<\alpha(0,05)$. Maka dapat disimpulkan bahwa Ho yang menyatakan bahwa pengembangan karir, semangat kerja dan motivasi tidak berpengaruh signifikan terhadap kinerja karyawan pada pT.Perkebunan Nusantara II Medan ditolak. 
b. Uji Parsial (Uji t)

Uji parsial dilakukan untuk mengetahui pengaruh masing-masing variabel bebas (pengembangan karir, semangat kerja atau motivasi) terhadap variabel terikat (kinerja karyawan). Pengaruh variabel bebas secara parsial dapat dilihat dengan membandingkan nilai $t_{\text {hitung }}$ dengan nilai $t_{\text {tabel }}$ untuk masing-masing variabel atau dengan membandingkan besarnya nilai sig. masing-masing variabel bebas dengan besarnya alpha yang digunakan dalam penelitian ini. Nilai $t_{\text {hitung }}$ dan nilai sig. masing-masing variabel bebas dapat dilihat pada out put SPSS berikut.

Tabel 28.

Coefficients $^{\mathrm{a}}$

\begin{tabular}{|ll|r|r|r|r|r|}
\hline \multirow{2}{*}{ Model } & \multicolumn{2}{|c|}{$\begin{array}{l}\text { Unstandardized } \\
\text { Coefficients }\end{array}$} & \multicolumn{2}{l|}{$\begin{array}{l}\text { Standardized } \\
\text { Coefficient }\end{array}$} & & \\
\cline { 2 - 5 } & \multicolumn{1}{|c|}{$\mathrm{B}$} & Std. Error & Beta & $\mathrm{t}$ & Sig. \\
\hline 1 & (Constant) & 4.234 & 1.982 & & 2.136 & .037 \\
& Pengembangan karir & .226 & .110 & .223 & 2.056 & .045 \\
& Semangat kerja & .366 & .093 & .420 & 3.929 & .000 \\
& Motivasi & .233 & .077 & .304 & 3.009 & .004 \\
\hline
\end{tabular}

a. Dependent Variabel: kinerja karyawan

Sumber: Data primer diolah

Dari Tabel 28 dapat dilihat bahwa secara parsial, pengembangan karir, semangat kerja dan motivasi berpengaruh positif dan signifikan terhadap kinerja karyawan pada PT. Perkebunan Nusantara II Medan. Hal ini dapat dilihat dari perbandingan nilai $t_{\text {hitung }}$ (dilihat dari out-put SPSS) dengan nilai $t_{\text {tabel }}($ dilihat dari tabel $t$ ).

Untuk variabel bebas pengembangan karir, nilai $t_{\text {hitung }}(2,056)>$ nilai $t_{\text {tabel }}(1,673)$, uji satu arah $(\alpha=0,05)$ dengan daerah penolakan di ekor kurva sebelah kanan atau nilai sig. $(0,045)<\alpha(0,05)$. Maka dapat disimpulkan bahwa Hipotesa nol yang menyatakan bahwa pengembangan karir tidak berpengaruh positif dan signifikan terhadap kinerja karyawan, ditolak.Dengan demikian, apabila indikator pengembangan karir ( keadilan karir, perhatian penyelia, kesempatan, minat, kepuasan karir) disesuaikan dengan kebutuhan karyawan maka kinerja karyawan akan meningkat. Maka untuk itu, pimpinan perusahaan perlu memperhatikan pemberian kesempatan yang sama kepada karyawan untuk mengembangkan karir mereka, memberikan dukungan bagi karyawan serta memberikan informasi yang cukup tentang pengembangan karir di PT. Perkebunan Nusantara II 
Medan, supaya karyawan dapat mempersiapkan diri dengan baik untuk peluang-peluang yang ada.

Untuk variabel bebas semangat kerja, nilai $t_{\text {hitung }}(3,929)>$ nilai $t_{\text {tabel }}(1,673)$, uji satu arah $(\alpha=0,05)$ dengan daerah penolakan di ekor kurva sebelah kanan atau nilai sig. $(0,000)<\alpha(0,05)$. Maka dapat disimpulkan bahwa Hipotesa nol yang menyatakan bahwa semangat kerja tidak berpengaruh positif dan signifikan terhadap kinerja karyawan, ditolak. Dengan demikian apabila indikator semangat kerja (absensi, kerja sama, kepuasan kerja, sikap dan tingkah laku) diperbaiki maka kinerja karyawan akan meningkat. Maka untuk itu, pimpinan perusahaan perlu memperhatikan masalah kehadiran, membina karyawan untuk mampu dan bersedia bekerja sama serta membina sikap dan tingkah laku dalam melaksanakan tugas, agar selalu mematuhi aturan-aturan yang ada di perusahaan.

Untuk variabel bebas motivasi, nilai $t_{\text {hitung }}(3,009)>$ nilai $t_{\text {tabel }}$ $(1,673)$, uji satu arah $(\alpha=0,05)$ dengan daerah penolakan di ekor kurva sebelah kanan atau nilai sig. $(0,004)<\alpha(0,05)$. Maka dapat disimpulkan bahwa Hipotesa nol yang menyatakan bahwa motivasi tidak berpengaruh positif dan signifikan terhadap kinerja karyawan, ditolak. Dengan demikian, apabila indikator motivasi (daya pendorong, kemauan, kerelaan, ketrampilan, tanggung jawab) lebih diperhatikan perusahaan maka kinerja karyawan dapat ditingkatkan. Maka untuk itu, pimpinan PT. Perkebunan Nusantara II Medan perlu lebih memperhatikan karyawan untuk menumbuhkan kerelaan bekerja dengan kesadaran sendiri, memanfaatkan ketrampilan yang dimiliki seoptimal mungkin dan bertanggungjawab untuk tugas yang dibebankan kepada mereka masing-masing.

\section{Regresi Berganda}

Penelitian ini mau melihat bagaimana hubungan antara variabel bebas (pengembangan karir, semangat kerja dan motivasi) terhadap variabel terikat (kinerja karyawan) dan sekaligus mau mengestimasi kinerja karyawan berdasarkan pengembangan karir, semangat kerja dan motivasi. Untuk itu digunakan regresi berganda karena variabel bebas lebih dari satu.

Berdasarkan Tabel 27 (Out put SPSS), persamaan regresi berganda dirumuskan sebagai berikut: $\mathrm{Y}=4,234+0,226 \mathrm{X}_{1}+0,366 \mathrm{X}_{2}+$ $0,233 \mathrm{X}_{3}+\mathrm{e}_{\mathrm{i}}$ 
Persamaan regresi berganda tersebut dapat dijelaskan sebagai berikut:

Nilai konstanta sebesar 4,234 dapat diartikan bahwa jika pengembangan karir, semangat kerja dan motivasi nol, maka kinerja karyawan sebesar 4,234 satuan

Koefisien regresi pengembangan karir $\left(\mathrm{X}_{1}\right)$ sebesar 0,226 artinya bahwa pengembangan karir berhubungan positif dengan kinerja karyawan pada PT. Perkebunan Nusantara II Medan. Jika pengembangan karir diperbaiki satu satuan maka kinerja karyawan juga akan semakin meningkat sebesar 0,226 satuan dan sebaliknya.

Koefisien regresi semangat kerja $\left(\mathrm{X}_{2}\right)$ sebesar 0,366 artinya bahwa semangat kerja berhubungan positif dengan kinerja karyawan pada PT. Perkebunan Nusantara II Medan. Jika semangat kerja karyawan naik satu satuan maka kinerja karyawan juga akan semakin meningkat sebesar 0,366 satuan dan sebaliknya.

Koefisien regresi motivasi $\left(\mathrm{X}_{3}\right)$ sebesar 0,233 artinya bahwa motivasi berhubungan positif dengan kinerja karyawan pada PT. Perkebunan Nusantara II Medan. Jika motivasi karyawan naik satu satuan maka kinerja karyawan juga akan semakin meningkat sebesar 0,233 satuan dan sebaliknya.

Dari tiga variabel bebas (pengembangan karir, semangat kerja dan motivasi), yang mempunyai pengaruh paling besar adalah variabel semangat kerja karena memiliki koefisien regresi yang paling tinggi yaitu 0,366 .

Untuk melihat seberapa besar kemampuan variabel bebas (pengembangan karir, semangat kerja dan motivasi) menjelaskan variasi variabel terikat (kinerja karyawan) pada PT. Perkebunan Nusantara II Medan, dapat dilihat dari koefisien determinasi $\left(\mathrm{R}^{2}\right)$ dari Out put SPSS yang ditunjukkan pada tabel berikut:

Tabel 29.

Model Summary

\begin{tabular}{|l|l|l|l|l|}
\hline Model & $R$ & $\begin{array}{l}\mathrm{R} \\
\text { Square }\end{array}$ & $\begin{array}{l}\text { Adjusted R } \\
\text { Square }\end{array}$ & $\begin{array}{l}\text { Std. Error of the } \\
\text { Estimate }\end{array}$ \\
\hline 1 & $.786^{\mathrm{a}}$ & .618 & .597 & 1.411 \\
\hline
\end{tabular}

a. Predictors: (Constant), pengembangan karir, semangat kerja, motivasi

b. Dependent Variable: kinerja karyawan

Sumber: Data primer diolah 
Dari Tabel 29 dapat dilihat bahwa nilai koefisien determinasi $\left(\mathrm{R}^{2}\right)$ sebesar 0,618, artinya bahwa kemampuan variabel bebas (pengembangan karir, semangat kerja dan motivasi) untuk menjelaskan variasi kinerja karyawan sebesar 61,8\% dan sisanya sebesar 38,2\% (100\% - 61,8\%) dijelaskan oleh variabel lain yang tidak termasuk dalam model, misalnya kompensasi, gaya kepemimpinan, lingkungan kerja dan lain sebagainya.

\section{Kesimpulan}

1. Persamaan regresi linier berganda dalam penelitian ini adalah sebagai berikuta:

$\mathrm{Y}=4,234+0,226 \mathrm{X}_{1}+0,366 \mathrm{X}_{2}+0,233 \mathrm{X}_{3}+\mathrm{e}_{\mathrm{i}}$.

Artinya, pengembangan karir, semangat kerja dan motivasi berhubungan positif dengan kinerja karyawan pada T. Perkebunan Nusantara II Medan. Variabel yang paling dominan pengaruhnya terhadap kinerja karyawan adalah semangat kerja karena memiliki koefisien regresi paling besar yaitu 0,366 .

2. Pengembangan karir, semangat kerja dan motivasi secara simultan berpengaruh signifikan terhadap kinerja karyawan pada PT. Perkebunan Nusantara II Medan. Hal ini dilihat dari nilai $F_{\text {hitung }}$ $(29,142)>$ nilai $F_{\text {tabel }}(2,78)$ dan nilai sig. $(0,000)<\alpha(0,05)$.

3. Pengembangan karir, semangat kerja dan motivasi secara parsial berpengaruh signifikan terhadap kinerja karyawan pada PT. Perkebunan Nusantara II Medan. Hal ini dilihat dari uji t, dimana untuk pengembangan karir, nilai $t_{\text {hitung }}(2,056)>$ nilai $t_{\text {tabel }}(1,673)$, uji satu arah $(\alpha=0,05)$ dengan daerah penolakan di ekor kurva sebelah kanan atau nilai sig. $(0,045)<\alpha(0,05)$. Untuk semangat kerja, nilai $t_{\text {hitung }}(3,929)>$ nilai $t_{\text {tabel }}(1,673)$, uji satu arah $(\alpha=0,05)$ dengan daerah penolakan di ekor kurva sebelah kanan atau nilai sig. $(0,000)$ $<\alpha(0,05)$. Untuk motivasi, nilai $t_{\text {hitung }}(3,009)>$ nilai $t_{\text {tabel }}(1,673)$, uji satu arah $(\alpha=0,05)$ dengan daerah penolakan di ekor kurva sebelah kanan atau nilai sig. $(0,004)<\alpha(0,05)$.

4. Koefisien determinasi $\left(\mathrm{R}^{2}\right)$ sebesar 0,618 , artinya bahwa kemampuan variabel bebas (pengembangan karir, semangat kerja dan motivasi) untuk menjelaskan variasi kinerja karyawan sebesar $61,8 \%$ dan sisanya sebesar 38,2\% (100\% - 61,8\%) dijelaskan oleh variabel lain 
yang tidak termasuk dalam model, misalnya kompensasi, gaya kepemimpinan, lingkungan kerja dan lain sebagainya.

\section{Saran}

1. Pimpinan PT. Perkebunan Nusantara II Medan, perlu memberikan kesempatan yang sama, dukungan bagi karyawan yang memiliki potensi untuk mengembangkan karir.

2. Pimpinan PT. Perkebunan Nusantara II Medan, perlu menumbuhkan kerelaan karyawan untuk bekerja dengan kesadaran sendiri serta kemauan untuk bekerja sama satu sama lain.

3. Pimpinan PT. Perkebunan Nusantara II Medan, perlu melakukan penilaian kinerja secara periodik sebagai umpan balik bagi karyawan dimana hal tersebut dapat menjadi motivasi bagi karyawan untuk bekerja semakin sungguh-sungguh.

\section{Daftar Pustaka}

Alex S. Nitisemito, 2010. Manajemen Sumber Daya Manusia. Edisi Ketiga. Jakarta: Ghalia Indonesia

Edy, Sutrisno. 2009. Manajemen Sumber Daya Manusia. Jakarta: Kencana Perdana Media Grup

Flippo, Edwin B.2000. Manajemen Sumber Daya Manusia. Jakarta. PT. Gelora Aksara Pratama

Gibson, M. Robbins 2010. Manajemen Sumber Daya Manusia. Cetakan Kedua. Jakarta: Erlangga

Martoya, Susilo. 2007. Manajemen Sumber Daya Manusia. Edisi Kedelapan. Yogyakarta: BPFE

Mangkunegara, A.A. Anwar Prabu. 2000. Manajemen Sumber Daya Manusia Perusahaan. Penerbit: Remaja Rosdakarya, Bandung

Martoyo, 2007. Manajemen Sumber Daya Manusia. Edisi ketiga, Cetakan Kedelapan, Jakarta: Rajawali Press 
Siagian Sondang P. 2004. Paradigma Baru Manajemen Sumber Daya Manusia. Cetakan Pertama, Bandung: Alfabeta

Sunyoto, D. 2012.Manajemen Sumber Daya Manusia. Jakarta: Kencana Prenada Media Grup

Saydam, Gouzali. 2005. Manajemen Sumber Daya Manusia (suatu pendekatan mikro). Jakarta: Djambatan 